\title{
時代を背景としての身長の統計的観察
}

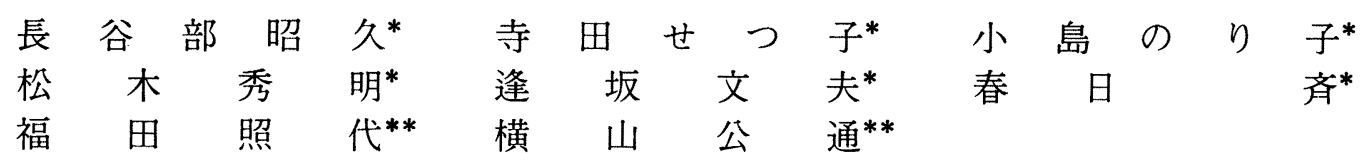

\section{A Statistical Investigation of Age-Height Against Historical Period}

\author{
Akihisa HASEBE, Setsuko TERADA(Miss), Noriko KOJI MA(Miss), ${ }^{*}$ \\ Hideaki MATSUKI, Fumio OSAKA, Hitoshi KASUGA* \\ Teruyo FUKUDA(Mrs), ${ }^{* *}$ Hiromichi YOKOYAMA**
}

Changes in growth in regards to historical period were examined using Ministry of Education statistics. Furthermore, results of investigation concerning future possibilities as against the recent of appearance growth acceleration are also presented as follows.

1) The phenomena of growth acceleration and retardation can be observed, not by viewing data in terms of date of birth, but by measurement year, in other words, these phenomena are governed not by the individuals age, but according to period of history.

2) Growth acceleration was not were acceleration but appears as growth advancement.

3) Growth degeneration at the beginning of World War II and degeneration in 1937 and 38 were due in large measure to the affects of natural calamity.

4) The state in the post-war period was a re-appearance of the Meiji Era. Recovery in the immediate post-war years can be thought to be the result of improvement in individual nutrition, and this correlates: to the average living conditions in pre-war years. After this, nutritional improvement in the mother's body became a factor and growth acceleration was maintained. However, from 1964, which can be seen as a return to the living conditions of the early Shōwa Era, growth acceleration became slowed and the present increase in height can be

\footnotetext{
*東海大学医学部公衆衛生学教室

**神奈川県立栄養短期大学

* Department of Public Health, Tokai University School of Medicine

** Kanagawa Prefectural junior College of Nutrition
} 
considered a natural tendency and no longer viewed as growth acceleration.

5) The influence of unfavorable nutritional conditions in the final growth stage inhibits final height, but unfavorable influences in eariler growth stages seem to be remedied by nutritional improvement.

6) It was seen that, besides the nutrition of the individual, the nutritional improvement of the mother has a great effect on the child.

\section{1. 諸言}

発育に関与する要因の検討は数多く報告さ れている。大山蜡を纱象として種々の 要因別に相関分析した結果，栄養に関する因 子で相関の高いことを述べている。

一方，栄養が発育におよぼす影響に関して の報告も枚挙に遑がない。乳児期に関しては 母乳とその他の栄養方法による差異, 小児期 における第 2 次世界大戦後の学校給食実施校 と非実施校生徒間の比較, また国民のほぼ全 員に食糧不足の影響があったと考えられる第 2 次世界大戦中の発育遅滞現象 ${ }^{4), 5)}$ など, い ずれも栄養不足による発育不良が指摘されて いる。

しかし, 第 2 次世界大戦後はその発育遅滞 現象に対する代償的発育がみられたことも報 告 $^{4), 5), 6) ~ か ゙ あ る 。 ~}$

そこで著者は戦後30年の身長経過と戦前を 比較することから逆に時代背景を推察できる と考えた。また, 戦後の発育促進化現象につ いても検討し，いささかの知見を得たので報 告する。

\section{2. 調査対象ならびに調査方法}

文部省体育局発行の昭和 49 年度体力 · 運動 能力調查報告書 ${ }^{7)}$ により1900年 (明治33年) か ら1974年（昭和49年）までの 6 才より，18才 までの平均身長を抽出した。18才までとした のは前記文部省統計から，18才以上は身長増 加がみられなかったからである。

調査方法は, まず出生年代別の従断的発育 経過を観察するために, 出生年代別発育曲線 を画き，つぎに同年令の時代推移を観る意味 で各年令の年代ごとの身長を結んだ。
本対象は 6 才以上であるため, 第 2 発育急 進期 ${ }^{8)}$ が観察できる。したがって, 各成長曲 線により成長の変向年令を定め, 第 1 充実期, 第 2 発育急進期, そして第 2 充実期各期の平 均発育勾配を各出生年代別に最少二乗法によ り求めた。同時に 6 才から18才までの各出生 年代別平均発育勾配も同様に求めた。

また同一年令の身長の時代推移においても, 第 2 次世界大戦前, 戦後に分け, 各年令にお ける身長の回帰勾配を求め比較した。

\section{3. 調査結果}

まず基礎資料として, 日本を中心とする世 界史的年表を示すと, 次のとおりである。

1905年 日露戦争にて日本が勝利

1914年 第 1 次世界大戦

1923年 関東大震災

1937年 日華事変

1939年 第 2 次世界大戦

1941年 太平洋戦争

1945年 日本無条件降伏

この表を念頭におき以下のごとく解析する。

\section{A. 身長の時代推移}

出生年代別, 年令別平均身長の縦断的グラ

フを図 I - 1,2に示した。

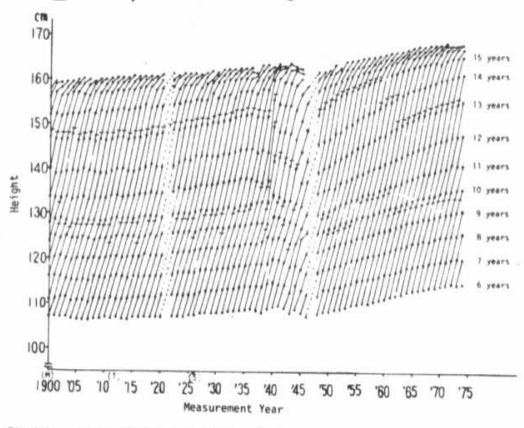

Fig. I-1 Longitudinal representation showing by date
height per his torical period for ages 6 to 18 . (mole) 


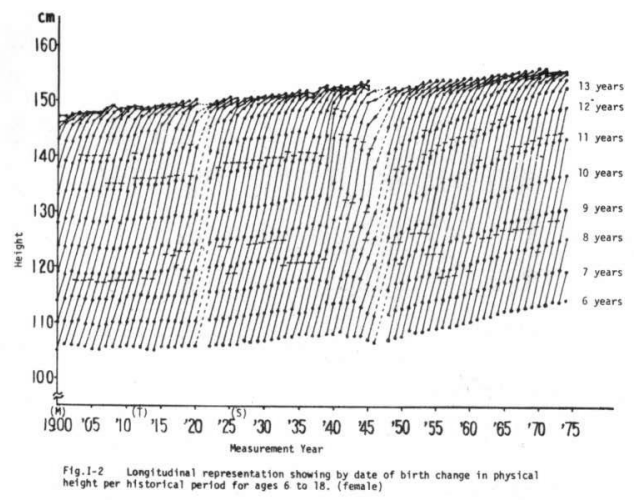

また，出生年代別に 6 才時，18才時の身長 の時代推移を罒 II-1,2に示した。

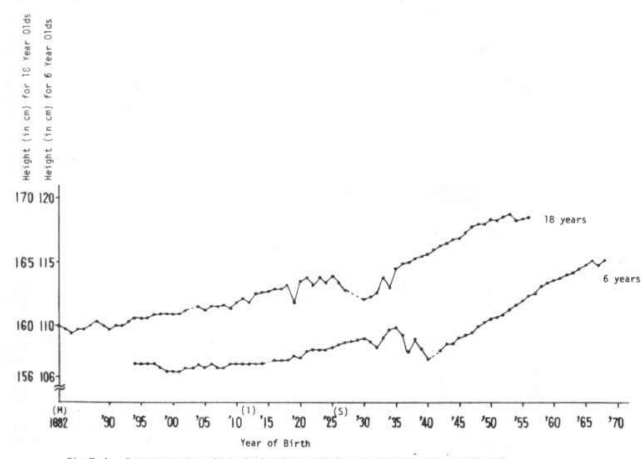

Fig. I- -1 Representation of physt cal peight per historical period at 6 years old
and 18 years old arranged by year of birth. (male)

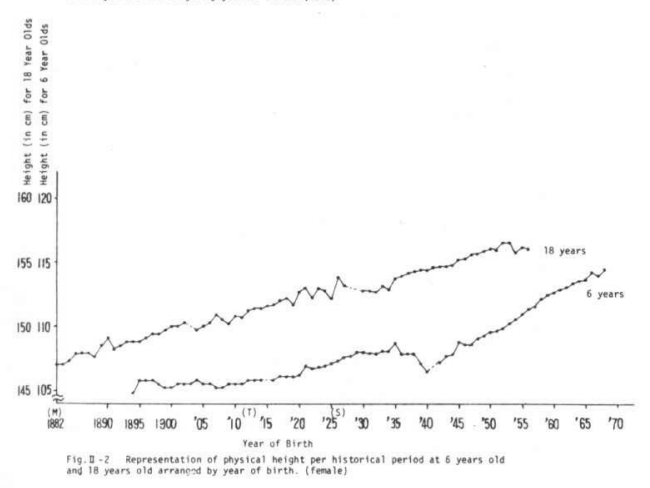

まず，6才時の男子の身長は図 II - 1 のご とく，時代を大きく 4 期に分けて観察できる。 第 1 期は1894年生まれから 1914年生まれま での変化が殆んどみられない時期である。第 2 期は1916年生まれから1930年生まれまでの 発育促進化傾向がみられる時期, 第 3 期は 19 31年生まれから1940年生まれまでの動摇の大
きい時期，そして第 4 期は1943年生まれ以後 の発育促進が顕著にみられる時期である。

一方, 成熟期とみられる18才時の身長推移 は 3 期に大別される。すなわち, 第 1 期は 18 82年生まれから1918年生まれまでの身長増加 期，第 2 期は1919年生まれから1930年生まれ までの動摇期, 第 3 期は1931年生まれ以後の 急増期である。

以上のごとく，6才時の身長の高低と18才 時のそれは一致していないことがわかった。

つぎに，女子の6才時身長の時代推移をみ ると, 眓 II - 2 に示すごとく, 男子同様 4 期 に大別できる。すなわち，1920年生まれまで の著変のみられない第 1 期, 第 2 期は1921年 生まれから1929年生まれまでの漸増期, 第3期 は1930年生まれから1940年生まれまでの停滞 もしくは低下時期，そして1942年生まれ以後 の急増期である。

また，成熟期である18才に関しての身長の 時代推移は 3 期に大別される。すなわち, 第 1 期は高低の動摇を示しながら平均的には増 加傾向を示す1918年生まれまでの時期, 第 2 期は1919年生まれから1934年生まれまでの変 化が激しく,また低迷の時期, そして第 3 期 は1935年生まれ以後の増加期である。

なお，女子においても 6 才時身長と18才時 身長との間には高低の関係のないことがわか つた。

そこで測定年度別に 6 才時, 18才時各身長 推移をみる意味で図而ー1,2にこれを示した。

これらから身長の大きな変動は性別, 出生 年代，また年令を問わず，ほぼ時代によって 規制されていることがわかった。

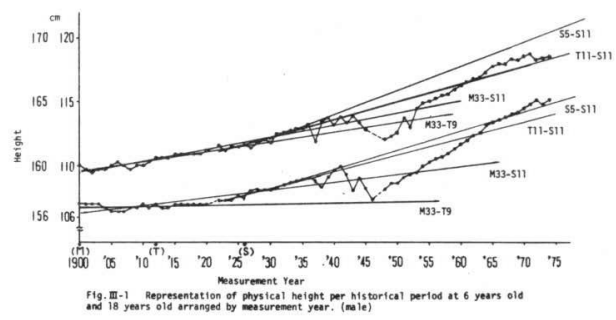




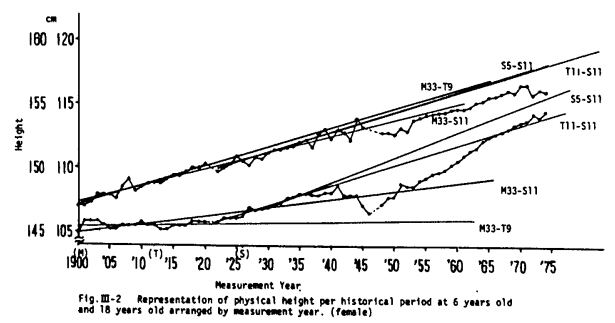

B. 出生年代別発育状況

各出生年代別発育状況をみると男女ともに 特定時代を除けば，いわゆる発育急進期が認 められる。

したがって 6 才からの勾配が変向するまで を第 1 充実期とし,つぎの変向年令までを第 2 発育急進期, それ以後18才までを第 2 充実期と 考え, 各出生年代別にこれらの勾配を求めた。 勾配の求め方は最小二乗法によった。まず 男子における第 1 充実期から第 2 発育急進期 の変向年令は図 I -1のごとく, 1890年生まれ では12才で認められ，1891年以後1933年生ま れまでは散発的変動はあるが11才で認められ た。第 2 次大戦中は不明であるが, 戦後は 19 40年生まれ以後は $10 才 に$ 年令は低下した。

これを平均身長でみると大戦前は最低 124 . $8 \mathrm{~cm}$, 大戦後は $127.2 \mathrm{~cm}$ 示し, 以後現代まで で身長は増加の傾向を示し, 最終は $136.0 \mathrm{~cm}$ が変向年令となっている。

一方, 第 2 発育急進期から第 2 充実期への 変向年令は, 大戦前は1894年の15才を除くと おおむね14才として推移していたが，1925年 生まれ以後暫く特異な発育状態を示した。大 戦後は15才で始まり，1945年生まれで 1 年若 年化して14才，1949年で再度 1 年若年化して 13才が変向年令で現代に至っている。

以上を平均身長でみると大戦前は最低が 14 $6.4 \mathrm{~cm}$ で, 大戦直前まで漸次増加傾向を示し たが，大戦後は154.2cmから始まり，1944年 生まれが $160.6 \mathrm{~cm}$ で変向期に達したものが 1945 年生まれは14才で $154.4 \mathrm{~cm}$ の身長で変向期を迎 えた。また, 1948年生まれの156.4cmに達する と 1949年で 1 年若年化して現代に至っている。
つぎに女子に於ける第 1 充実期と第 2 発育 急進期の変向年令は図I-2のごとく男子と異 なり非常に動摇が激しく現われている。すな わち, 統計の初期は 9 才時に変向期がみられ 1903年生まれが10才，1904, 5年生まれが 9 才 以後10才となり，1916年，1917年生まれが 9 才で1931年生まれ以後の動摇期に移行してい る。大戦後は1941年生まれの9才を除いて10才 から始まり, 1945年生まれで 9 才, 1948年生ま れで 8才と若年化し, 以後1952年, 1962年生ま れの 8 才を除き 9 才が変向年令となっている。

平均身長でみると大戦前は最低值が 118.5 $\mathrm{cm}$ を示し, 大戦後は $119.9 \mathrm{~cm}$, 多くの出生年代 の傾向は $126.2 \mathrm{~cm}$ か $128.0 \mathrm{~cm}$ まで増加し, 12 $4.0 \mathrm{~cm}$ に低下して以後は漸次増加し $130.8 \mathrm{~cm}$ ま で増加した。

第 2 発育急進期から第 2 充実期への移行年 令は1895年生まれまでは13才でみられ, 以後 大戦変動期までは散発的に13才がみられる他 12才でみられた。大戦後も1940年生まれの13 才，1950年，1953年生まれの11才以外は12才 で変向期が認められたものが1955年生まれ以 後は11才で変向期が落ち着いている。

平均身長でみると, 大戦前の最低は 133.8 $\mathrm{cm} ， 1891$ 年生まれは $139.1 \mathrm{~cm}$ ，これが1895年 となって 1 才若令化し, $133.8 \mathrm{~cm}$ に減少し, 大 戦前動摇期前の最高が $139.7 \mathrm{~cm}$ に達した。大 戦後は $136.8 \mathrm{~cm}, 12$ 才に始まり $146.8 \mathrm{~cm}$ に達す ると1955年生まれで 1 才若令化し，11才で14 $1.0 \mathrm{~cm}$ ，そして最近は $143.7 \mathrm{~cm}$ に達している。

以上の出生年代別年令分割により, 第 1 充 実期，第 2 発育急進期，第 2 充実期各々の勾 配を求め, 出生年代別にプロットしたものが 図 $\mathrm{N}-1,2$ である。

まず, 男子の第 1 充実期は1930年生まれか ら1939年生まれまでの動摇期を除くと全体的 に勾配が増加している。第 2 発育急進期は前 者に比し増減が激しい。そのうちで1906年生 まれまでは漸減傾向, 1912年生まれから 1922 年生まれまでは漸増傾向, 以後1939年生まれ 

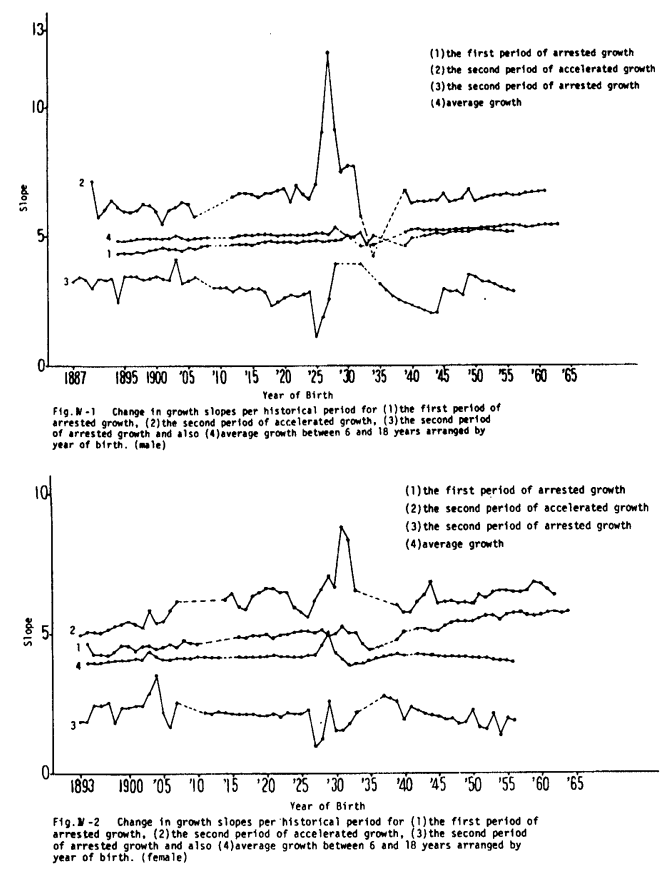

までは特異であり，第 2 次世界大戦後は一部 の動摇を除いて漸増傾向を示した。第 2 充実 期に関しては戦前, 戦後, 型は異っているが 漸減傾向を示している。戦後のカーブは階段 状下降を示している。

以上をまとめて 6 才から18才までの平均成 長勾配をみると, 戦前は微増し, 戦後は漸減 と逆の状態がみられる。

女子においても男子と同様な傾向がみられ る。すなわち第 1 充実期は漸増傾向, 第 2 発 育急進期も漸増傾向, 第 2 充実期は漸減傾向 そして，6才から18才までは戦前が微増, 戦 後は漸減傾向である。

C. 第 2 次世界大戦前・後における年令別 身長の時代推移

同一年令における身長を時代的に観察した 結果は第 1 項に記したが，いずれにしても 19 35年までと 1948年以後は各々ほぼ直線的変化 とみられるため，それぞれ年令別に最小二乗 法を用い時代推移の変動勾配を求めてみた。 この結果を図 V-1,2に示した。

男子の大戦前は 6 才時の 0.06 に始まり，9

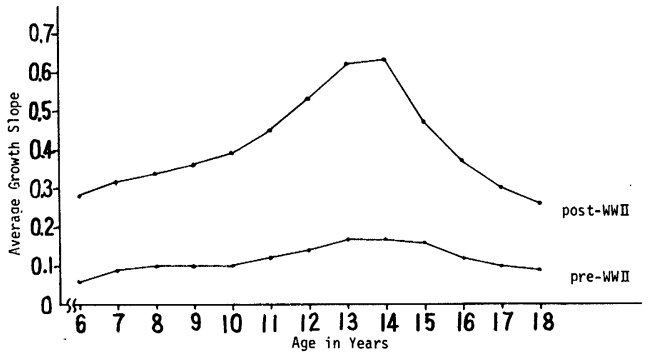

Fig. $\nabla-1 \quad$ Comparison of average growth slopes at each age for pre-WWII
and post-WWI periods. (male)

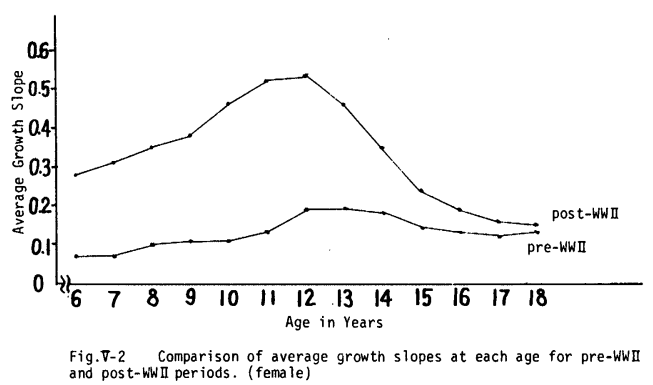

才まで増加し，10才で一旦低下したものが13 才でピークに達し，16才からは低下したが18 才時は 6 才時より勾配は大きかった。

一方, 戦後は 6 才の $0.29 に$ 始まり漸増し, 10才から急增し13才のピークでは $0.63 に$ に達し た。以後15才で激減し，これが次第に緩くな ク18才時は 6 才時の勾配を下迴るが, 戦前の 2.5倍の勾配を示した。

女子における大戦前は，6才時が0.06であ り, 6〜8才は漸増, 8〜10才はほぼ変らず, 11〜12才で急増している。12〜13才はプラト 一を呈し, 以後漸減傾向を示しているが, 18才 時でも 6 才時の 2 倍以上の勾配を示していた。

大戦後は男子同様に大部様相を異にし， 6 才時は $0.28 て ゙ 9$ 才まで漸増し，9才から11才 まで急増し，11〜12才はプラトーを呈し，こ のピークは0.53を示した。15才で 6 才時を下 廻る0.23にまで急減し, 18才まで漸減し, こ の時点の勾配は大戦前をやや上廻る程度とな っている。

いずれにしても，男女とも戦前は 6 才時勾 配より18才時勾配が大きいのに対し, 戦後は 18才が低下していること, 最大勾配は戦前に 
対し, 戦後では 1 年早く, 勾配減少も同様で ある。

\section{4. 考察}

\section{A. 発育の時代推移}

諸家の報告のとおり発育促進化現象は本検 討でも明らかである。

しかし，6才時身長の立ち上りは男子にお いては1919年生まれ以後で，近年では1942年 生まれからである。女子は1920年生まれ以後 で近年としては男子同様1942年生まれからで ある。男女間で立ち上りに差がみられたこと は今後検討の余地があるが, 近年の1942年生 まれ以後男女とも急激な上昇をみせた。この 出生年児の 6 才時は1948年であり，第 2 次世 界大戦後であった。また1936年生まれが 6 才 時, すなわち 1942年から身長低下を男女とも に示した。同時に，この1941,2年からほぼ全 年代に身長低下がみられた。これは大戦によ る食糧事情の悪影響による発育抑制と伝えら れている。しかし，1941.2両年は未だ太平洋 戦争は開戦当初で，これのみに起因したかど うかは疑問である。一方，この両年はほぼ全 国的な気象災害が記録 ${ }^{9)}$ されている。この気 象災害に大戦が加わって食糧不足が一層深刻 であったことがうかがえる。この観点による と1937·8年も同様で, 気像災害の記録 ${ }^{9)}$ と同 時に日清戦争の開戦によって食糧不足となっ た影響で発育抑制が現われたものと考えられ る。しかもこの発育抑制は特定年代にみられ るのではなく, 発育末期の男子では17〜18才 まで，女子では16〜17才まで年代のずれはあ るが全般的に認められた。

以上とは逆に，1948年から統計値が再掲さ れて以後の発育状況は, 年長になるにつれて 当初の発育促進が長期に延長されている傾向 がうかがわれる。しかし，18才の身長変遷を みると 6 才時には発育促進のみられた1928〜 30年生まれが最低值を示し, 以後1932年生ま れから一応連続の発育促進がみられ，6才時 身長とは無関係に推移していることがわかる。
また 6 才時凹凸の激しかった1931〜1940年生 まれは18才時には順調な身長増加を示した。 すなわち, 測定年による 6 才時, 18才時の 時代別グラフからもわかるように，各年令に おける身長の高低は時代によって規制されて いる。したがって, 発育初・中期における環 境の悪条件はそれ以後好転することにより容 易に回復するが，発育末期の悪条件はそのま まの状態で終ることのようにみえた。

そこで見方をかえて，もしも，大戦前の身 長変化の状態が続くとすると, 大戦時あるい は, 大戦後の身長变化と如何なる関係を示し たかを観察した。

すなわち，1900年から1920年まで，1900年 から1936年まで，1922年から1936年までそし て1930年から1936年までのおのおのの 6 才時, 18才時の身長の時代変化を最小二乗法によっ て求めた。

男子の 6 才時においては図 III-1に示すごと く1900年から1920年までの回帰直線は大戦後 の最低值1946年値の近くを通過していた。

つぎに戦前平均である1900年から1936年ま での回帰直線は1953年で交叉した。戦前の身 長増加立ち上りから増加終了までの1922年か ら1936年までの直線は1963年で交叉し, 戦前 最大増加を示した1930年から1936年までの直 線は1966〜 7 年間で交叉した。

一方，女子においても図吕一2のごとく6才 時の1900年から1920年の回帰直線は交叉はな いが，1946年の值が近位を示した。1900年か ら1936年までのそれは1950〜 1 年間で, 1922 年から1936年までは1967年でそれぞれ交叉し， 1930年から1936年までの直線には現在まで交 叉がみられなかった。

これらから, 大戦中は1920年頃までの生活 環境に低下し，1953年頃までは栄養改善によ る本人の回復力で戦前の状態まで回復し, 以 後母体栄養の改善と思われることによって昭 和初期の延長に追いついたと考えられる。し たがって以後の増加率は著明にはみられなく 
なっている。

一方，18才時の男子では，大戦中あるいは 直後が1920年までの回帰直線以下を示し，19 51年にわずか上迴るのをみせた。1953年が戦 前平均を上廻り，1962年で戦前身長増加期回 帰直線と交叉した。また戦前最大勾配時期と の交叉はみられなかった。

これも 6 才時と同様な考えが成立するが女 子の18才時においてはこの傾向はみられない。 これは戦前の18才女子の計測対象者に特異性 があったものと推察される。すなわち戦前女 子の高等教育就学者は少なく, 統計上に加わ る女子は生活環境が比較的に恵まれていたも のと考えられる。しかし，各回帰直線との交 叉はみられないが，やはり大戦後から1953年 まで，1970年までとそれぞれ変向点が認めら れる。したがって，大戦前と大戦後の被検者 層が類以していたならば，男子同様に各変向 点において回帰直線との交叉が認められたも のと考えられる。

以上のことから, 食糧事情の悪化の影響は 本人の場合, 第 2 充実期では回復不能であっ て，それ以前では回復可能である。また母体 栄養の影響がこれに関与してこれの改善は上 記回復能力を助長させるものと考えられる。

男子の1965年以後, 女子の1970年以後は栄 養以外の自然趨勢としての発育傾向を示すも のと思われる。

B. 発育促進化について

前記同一年代の身長の時代推移によっても それの増高がみられたが, 一方出生年代別発 育傾向からも第 2 発育急進期, および第 2 充 実期の若年化がみられたこと，第 1 充実期は 年次的にその勾配は漸増傾向にあり，第 2 発 育急進期も同様傾向を示すが，第 2 充実期の それは漸減傾向を示していること，ならびに 戦前, 戦後の年代別身長変化の比較において も発育の早期化，成熟の早期化がみられた。 すなわち，これは発育前進現象であると考え られる。
しかしながら, 最終身長の時代推移による増 高は認められたが男子 6 才時では1972年以後 18才では1971年以後に，女子においては 6 才 時は1972年以後，18才では1970年以後に身長 増高の停止が認められている。

\section{5.総括ならびに結語}

文部省統計を用い身長の時代的推移を検討 した。また近年の発育促進現象に対し将来 の可能性についても検討した結果はつぎのと おりである。

1. 発育促進, 遅滞現象のみられるのは出 生年代でなく測定年，すなわち時代によって 規制されている。

2，発育促進は単なる促進ではなく発育前 進現象である。

3. 太平洋戦争初期の身長低下, 日清戦争 開戦である1937,8年の低下は共通に天災での 食糧不足と戦争によってこれの輸入し難い為 の影響によるところも大であったもののよう である。

4. 大戦直後の生活環境; 特に栄養状態は 明治時代を再現している。大戦後の初期の回 復は本人の栄養改善による結果と考えられ， これは大戦前平均生活状態に一致していた。 以後母体の栄養改善によると思われる発育促 進は持続したが，昭和初期の生活状態になっ たとみられる1964年頃から発育促進は遅促化 し, 現代では自然趨勢的とみられ, 発育促進 はみられなくなった。

5. 栄養状態は発育末期時代の悪影響が最 終身長を抑制し, 発育期早期のものは栄養改 善により回復するもののようである。

6. 本人個体の栄養も勿論であるが，母体 の栄養改善も子供には大きな影響のあること が推察できる。

なお本論文の要旨は第36回日本公衆衛生学 会総会においてロ演した。

\section{参考文献}

1）大山良徳：幼児の身体発育に関連する 
主要因の選定に関する基礎的研究（第 1 報）, 体育学研究，19，87-98（1974）

2）船川幡夫他 3 名: 昭和35年度わが国の 乳幼児の身体発育状態について（第 3 報）， 出生後初期の栄養方法について, 小児保健研 究, 22，191-196(1964)

3）阿部睦男：戦後における児童・生徒の 発育促進に関する研究 (第 1 報), 仙台市小. 中学校児童・生徒について, 日衛誌, 15, 445-457(1960)

4) A. Kawahata, Y. Matsuura: The growth and Development of Japanese Pupils and Contributing Factors, 体育学 研究，13，312-321(1969)

5）木村邦彦：発育と環境一その 6 -, 看 護技術，12(2)，87-93(1966)

6) 勝木新次：戦後の日本における青少年 の身体発育，体力研究，4，1-24（1965）

7）文部省体育局：昭和49年度, 体力 - 運 動能力調査報告書（1975）

8）猪飼道夫・高石昌弘：身体発達と教育 P 18，第一法規出版株式会社，東京（1967）

9）東京天文台：理科年表，昭和46年，丸 善, 東京, 気204－206(1971) 